\title{
Portuguese Language
}

National Cancer Institute

\section{Source}

National Cancer Institute. Portuguese Language. NCI Thesaurus. Code C120586.

An Indo-European language that originated in Portugal. It is the official language of Portugal, Brazil, Mozambique, Angola, Cape Verde, Guinea-Bissau, and São Tomé and Príncipe. 